\title{
ASSESSMENT OF THE EFFECTS OF EDUCATIONAL TECHNOLOGY TOOLS ON STUDENT LEARNING OUTCOMES
}

\author{
Maria Georgiou \\ Northcentral University, USA \\ Cyprus Ministry of Education, Culture, Sport and Youth, Cyprus
}

\begin{abstract}
This study examined if there were any significant differences in students' achievement scores in science for three units that were taught using traditional methods of instruction and a unit that was taught using educational technology tools in instruction and specifically, interactive multimedia technology. A one-way repeated measures ANOVA was carried out to assess if the differences between the test means were significantly different. Findings showed that students' scores for the four units were significantly different, $\mathrm{F}(3,219)=22.702, \mathrm{p}<0.0005$. Students scored higher on the posttest after the use of interactive multimedia technology in instruction. The results of the current study indicate the need to change educational anticipations, as teaching methods become more active, student-centered and constructivist. Multimedia has attributes that can help students improve their learning and motivation while being engaged in active, student-centered and constructivist learning environments. The use of instructional interactive multimedia can satisfy more than one learning modality and can be more effective in meeting students' learning needs.
\end{abstract}

\section{KEYWORDS}

Active Learning, Constructivist Learning Environment, Multimedia

\section{INTRODUCTION}

Science teaching has changed in the last years to include a more constructivist instructional approach that is more student-centered and allows students to explore ideas and experience real life situations that promote problem-solving and critical thinking skills (Birgan, 2010; Dalal, 2014; Hunter \& Krantz, 2010). This student-centered approach promotes also creativity, collaboration and higher order thinking skills that are usually lacking in science students (So \& Kong, 2007; Ulusoy, 2011). Researchers have found that teaching science with a constructivist approach provides active, student-centered learning environments that can 
improve student interaction and allow knowledge construction (Adegoke, 2011, Butts, 2008). Constructivist learning environments represent contexts for problem-solving that allow students to construct knowledge through collaboration and self-reflection (Birgan, 2010).

Research has shown that students receiving instruction that is based on the use of technology learn $40 \%$ faster than students receiving a traditional-based instruction (Dalal, 2014; Stokes, 2011). Traditional-based instruction refers to an instructional communication where the instructor has the overall control in the classroom and sends the educational material to the students who mostly learn at the same pace (Delgado, 2007). Traditional methods of instruction include mostly lectures; focus on memorization of educational information by the students, and lack of the use of educational technology tools (Malik, 2010; Yamauchi, 2008).

Multimedia tools that combine text, audio, video, animation and images have been found to be progressive educational technology tools when used in the learning environment (Adegoke, 2011; Singleton, 2009). Research has shown that students memorize $20 \%$ of what they see, $30 \%$ of what they hear, $50 \%$ of what they see and hear, and $80 \%$ of what they see, hear and use (Chapman, 2013; Dalal, 2014). With multimedia, students can create their own learning sequence, control what they learn and how they learn, and become independent learners (Mazzotti, 2010). Educational technology tools such as multimedia can help difficult scientific concepts to be visually presented (Birgan, 2010). The use of multimedia in science can help students increase their emotional involvement because multimedia connects students with places that are hard to reach (Ulusoy, 2011). Moreover, with multimedia technology students can improve their learning in science and be actively engaged in the learning process (Malik, 2010; Morano, 2014). An instruction that is based on the use of multimedia technology provides visual and verbal explanations that can enhance students' understanding (Chapman, 2013). Moreover, multimedia can appeal to more than one sense and help increase students' success and motivation (Weiss, Kramarski, \& Talis, 2006). Motivation is connected to metacognition and when the students feel good about using and learning with multimedia then their metacognitive thinking may be urged (Cottrell, 2014; Dalal, 2014). Multimedia can motivate students because it can prompt curiosity and make students wonder about the world and real-life situations (Mazzotti, 2010; Ulusoy, 2011).

Constructivist learning environments include active learning and help promote critical thinking and problem-solving skills that can be enhanced through the use of educational technology tools such as multimedia (Butts, 2008; Du, 2013). An instruction that is based on the use of multimedia technology and applies the constructivist principles is more authentic and promotes collaboration among the students (Birgan, 2010). The use of multimedia can affect student learning and achievement because multimedia learning supports the idea that learning is a process of knowledge construction that promotes critical thinking and not a process where students passively receive information (Dalal, 2014; Singleton, 2009). A multimedia-based learning environment in which constructivist principles are applied can motivate students to want to learn because the constructivist theory is based on the idea of discovery learning that supports that students are motivated to learn (Johnson, 2009; Rhodes, 2013). Furthermore, with the use of multimedia technology in instruction students learn faster because the educational material is processed through various presentations that can improve student understanding (Dalal, 2014; Rhodes, 2013; Zheng, Yangt, Garcia, \& McCadden, 2008). In contrast to traditional methods of instruction, an instruction that is based on the use of educational technology tools such as multimedia, allows students to create their own learning sequence and this helps them develop and promote important skills, such as problem-solving and higher order 
IADIS International Journal on WWW/Internet

thinking, that are necessary in order to become independent learners (Adegoke, 2011; Cottrell, 2014; Kingsley \& Boone, 2008).

Students' achievement in science is usually low because of incompetent teaching methods and passive learning (Adegoke, 2011; Malik, 2010). The purpose of this study was to examine if there were any significant differences in students' achievement in science for three units that were taught using traditional methods of instruction and a unit that was taught using educational technology tools in instruction and specifically, interactive multimedia technology. The study focused on the following research question: Is there a significant difference between the four units and students' scores?

\section{METHODOLOGY}

The study was quantitative and used a quasi-experimental research design. A total of 320 third grade students constituted the population group because of their previous low retention rates in science (Papanastasiou \& Zembylas, 2004). The sample for this study was selected using a convenience sampling method and included a total of 74 students. Participants attended five 80 minute science lessons in which interactive multimedia technology was used. Specifically, the multimedia software program HyperStudio was used which is a tool that can be used for project-based learning and the creation of stacks of cards that may include text, images, animations, sounds and video (Garthwait, 2004).

Data were collected from pretest and posttest scores as well as from archival data that included students' tests scores for three past units in science that were taught using traditional methods of instruction. Statistical analyses were conducted using SPSS. Descriptive statistics such as means and standard deviations were used to describe the general tendencies in the data (Trochim \& Donnelly, 2008). Also, measures of central tendency were used to describe the average test score of the participants. One-way repeated measures ANOVA was conducted in order to compare students' scores on the tests for the four units and to determine whether the differences between the score means, were significantly different. Assumptions of the one-way repeated measures ANOVA were also tested.

\section{RESULTS AND DISCUSSION}

The gender demographics are shown in Table 1 and Figure 1. Thirty-nine participants were male and thirty-five were female.

Table 1. Descriptive statistics (Gender)

\begin{tabular}{llllll}
\hline & & Frequency & Percent & Valid Percent & Cumulative Percent \\
\hline \multirow{3}{*}{ Valid } & & & & \\
\cline { 2 - 6 } & Male & 39 & 52.7 & 52.7 & 52.7 \\
\cline { 2 - 6 } & Female & 35 & 47.3 & 47.3 & 100.0 \\
\hline
\end{tabular}




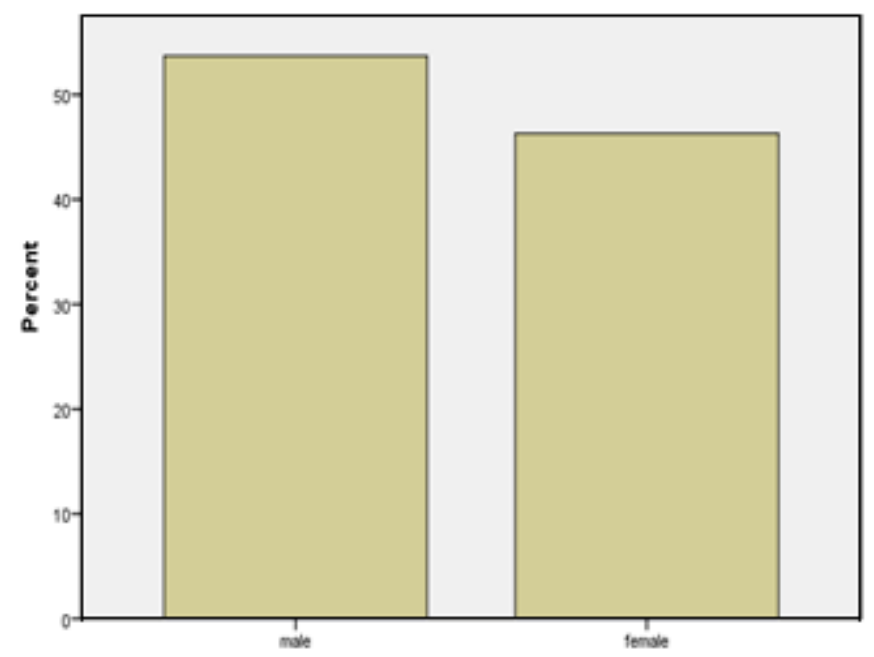

Figure 1. Descriptive statistics (gender)

The normality assumption for the one-way repeated measures ANOVA was tested. Students' science achievement (dependent variable) should be approximately normally distributed for the four science units (independent variable). The results of the Shapiro-Wilk's test and a visual review of the histograms, normal Q-Q plots and box plots showed that students' achievement was approximately normally distributed for the four units, with a skewness of -0.116 and a kurtosis of -0.942 (unit 1); a skewness of -0.079 and a kurtosis of -0.738 (unit 2); a skewness of -0.157 and a kurtosis of -0.781 (unit 3); and a skewness of -0.589 and a kurtosis of 0.218 (unit 4). As shown in Table 2, all z-values of skewness and kurtosis for the four units are within $+/$ 1.96. Consequently, the data are approximately normally distributed with regards to skewness and kurtosis.

Table 2. Skewness and kurtosis

\begin{tabular}{llll}
\hline & & Statistic & Std. Error \\
\hline $\mathrm{u} 1$ & Skewness & -.116 & .318 \\
\cline { 2 - 4 } & Kurtosis & -.942 & .632 \\
\hline $\mathrm{u} 2$ & Skewness & -.079 & .318 \\
\cline { 2 - 4 } & Kurtosis & -.738 & .632 \\
\hline $\mathrm{u} 3$ & Skewness & -.157 & .318 \\
\cline { 2 - 4 } & Kurtosis & -.781 & .632 \\
\hline $\mathrm{u} 4$ & Skewness & -.589 & .318 \\
\cline { 2 - 4 } & Kurtosis & .218 & .632 \\
\hline
\end{tabular}


IADIS International Journal on WWW/Internet

The results of the Shapiro-Wilk's test are presented in Table 3. All p-values are above 0.05 $(0.214,0.214,0.301$, and 0.096$)$. Therefore, the data are approximately normally distributed with regards to the Shapiro-Wilk test.

Table 3. Tests of normality

\begin{tabular}{ccccccc}
\hline & \multicolumn{2}{l}{ Kolmogorov-Smirnov $^{\text {a }}$} & \multicolumn{3}{c}{ Shapiro-Wilk } \\
\cline { 2 - 7 } & Statistic & df & Sig. & Statistic & df & Sig. \\
\hline $\mathrm{u} 1$ & .109 & 74 & .083 & .952 & 74 & .214 \\
\hline $\mathrm{u} 2$ & .101 & 74 & .201 & .952 & 74 & .214 \\
\hline $\mathrm{u} 3$ & .115 & 74 & .052 & .958 & 74 & .301 \\
\hline $\mathrm{u} 4$ & .121 & 74 & .041 & .967 & 74 & .096 \\
\hline
\end{tabular}

A visual review of the histograms, normal Q-Q plots and box plots for the four units was also made. All histograms have the approximate shape of a normal curve. The data are approximately normally distributed. Additionally, the data are approximately symmetrical as shown in Figures 2-5.

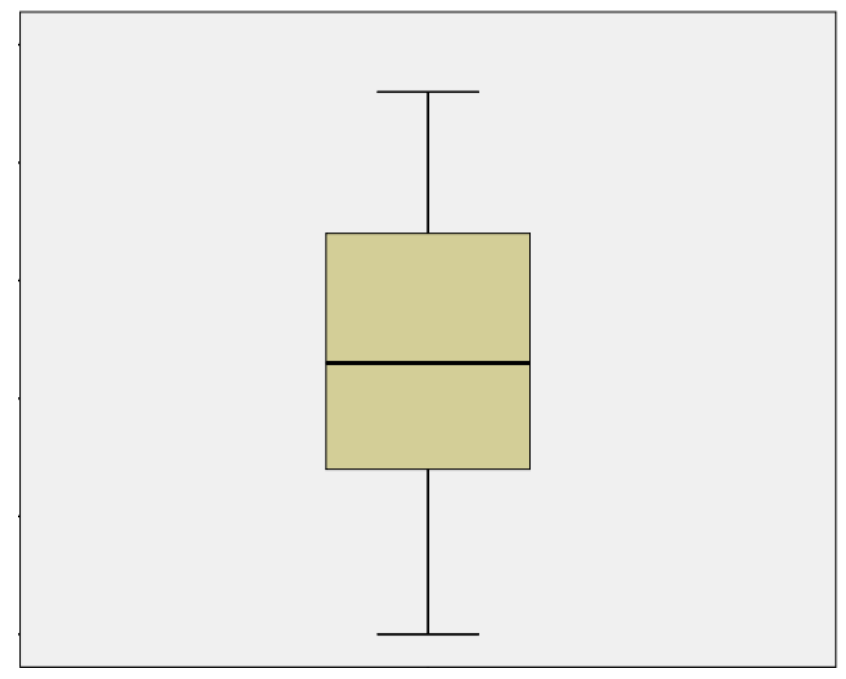

Figure 2. U1 box plot 


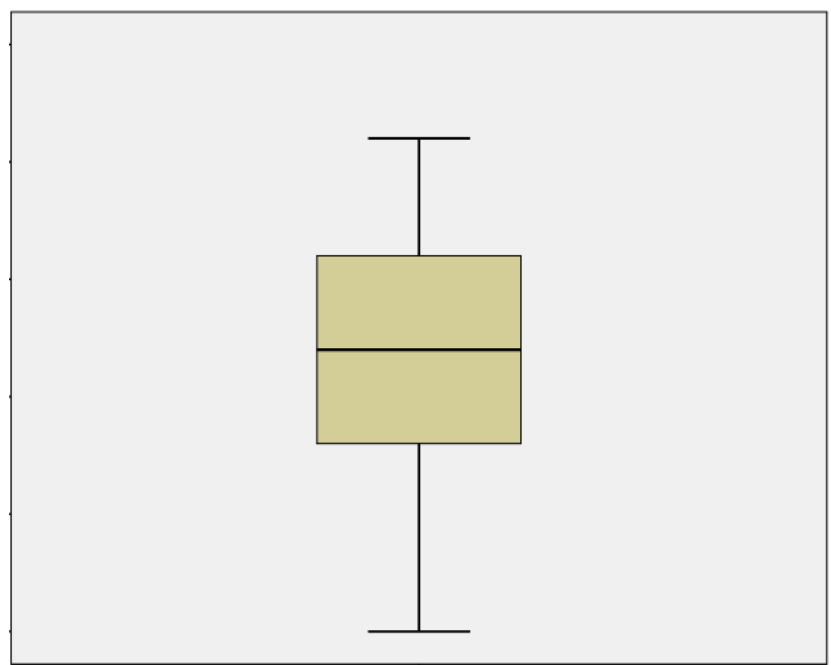

Figure 3. U2 box plot

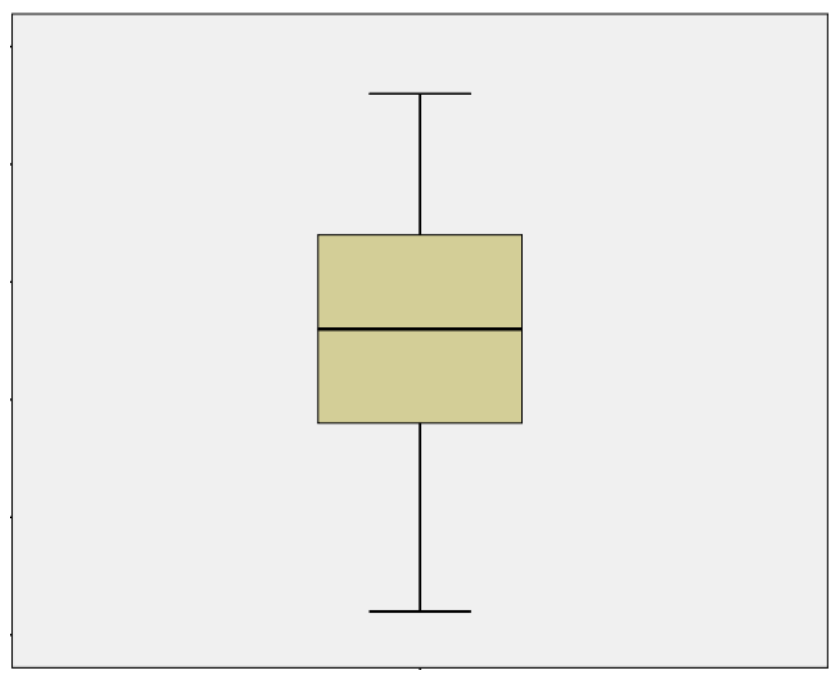

Figure 4. U3 box plot 
IADIS International Journal on WWW/Internet

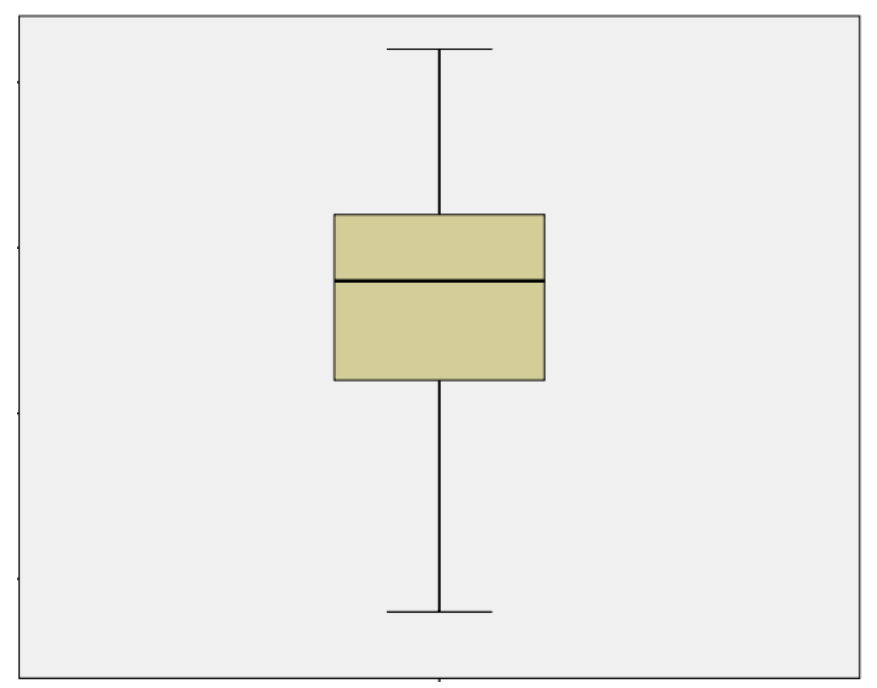

Figure 5. U4 box plot

Mauchly's Test of Sphericity was used in order to test the sphericity assumption. As shown in Table 4, the assumption of sphericity has been met, $x^{2}(5)=10.478, p=.063$. The data seem spherical and there is a $6,3 \%$ chance of finding the deviation from sphericity that is observed in this sample.

Table 4. Mauchly's test of sphericity

\begin{tabular}{|c|c|c|c|c|c|c|c|}
\hline \multirow{2}{*}{$\begin{array}{l}\text { Within Subjects } \\
\text { Effect }\end{array}$} & \multirow[t]{2}{*}{ Mauchly's W } & \multirow{2}{*}{$\begin{array}{l}\text { Approx. } \\
\text { Chi- } \\
\text { Square }\end{array}$} & \multirow[t]{2}{*}{ df } & \multirow[t]{2}{*}{ Sig. } & \multicolumn{3}{|l|}{ Epsilon $^{\mathbf{b}}$} \\
\hline & & & & & $\begin{array}{l}\text { Greenhouse- } \\
\text { Geisser }\end{array}$ & $\begin{array}{l}\text { Huynh- } \\
\text { Feldt }\end{array}$ & $\begin{array}{l}\text { Lower- } \\
\text { bound }\end{array}$ \\
\hline unit & .812 & 10.478 & 5 & .063 & .867 & .916 & .323 \\
\hline
\end{tabular}

The means and standard deviations are shown in Table 5. On average, the highest student scores were gained on the posttest for science unit $4(M=88.46)$. Figure 6 shows the means plot.

Table 5. Descriptive statistics

\begin{tabular}{llll}
\hline & Mean & Std. Deviation & N \\
\hline $\mathrm{u} 1$ & 86.4930 & 5.74581 & 74 \\
\hline $\mathrm{u} 2$ & 87.1375 & 5.23560 & 74 \\
\hline $\mathrm{u} 3$ & 88.1754 & 5.32678 & 74 \\
\hline $\mathrm{u} 4$ & 88.4657 & 3.56718 & 74 \\
\hline
\end{tabular}




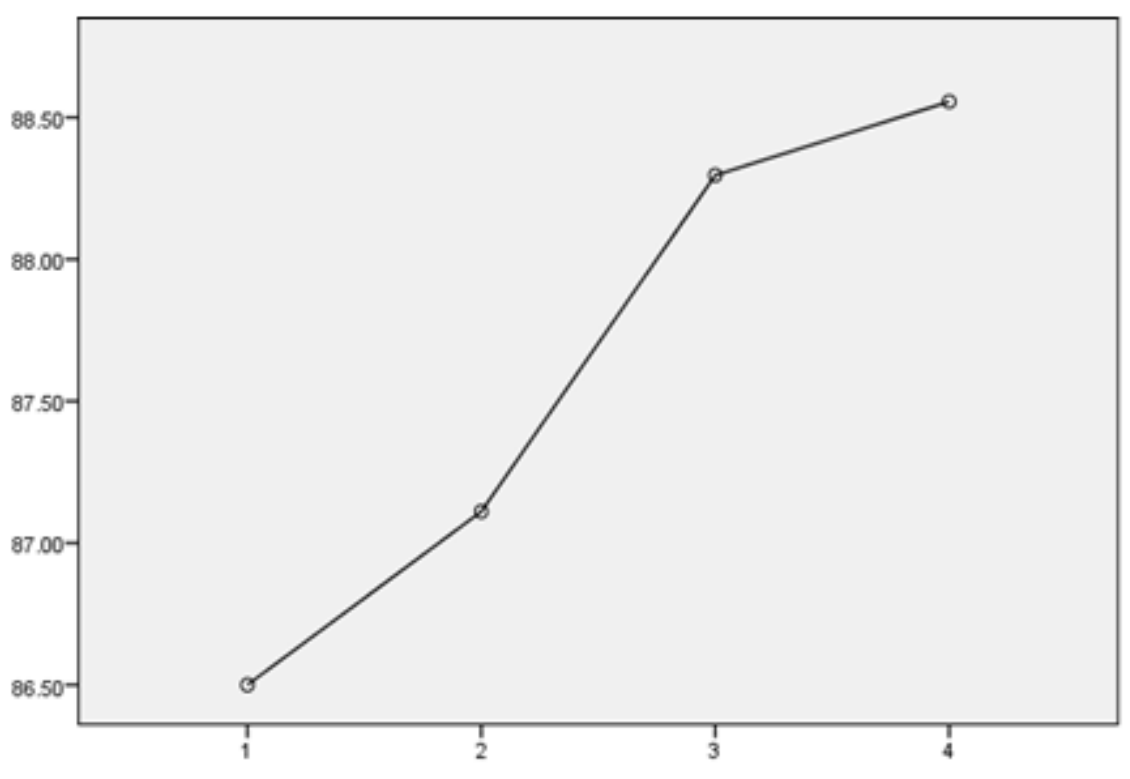

Figure 6. Estimated marginal means plot

The results from the multivariate tests are presented in Table 6 and show that there was a significant effect for the units, Wilks's Lambda $=.52, \mathrm{~F}(3,71)=12.659, \mathrm{p}<.0005$. The results indicate that students' scores increased significantly over time and over the units. The $\mathrm{p}<.05$ and therefore there is a statistically significant effect for the units. There was a change in students' scores throughout the units. There was a significant interaction between the units and students' scores and in fact, the science units had a significant effect on students' scores over time as revealed by the repeated measures.

Table 6. Multivariate tests

\begin{tabular}{lllllll}
\hline Effect & & Value & F & Hypothesis df & Error df & Sig. \\
\hline unit & Pillai's Trace & .427 & $12.659^{\mathrm{b}}$ & 3.000 & 71.000 & .000 \\
\cline { 2 - 7 } & Wilks' Lambda & .526 & $12.659^{\mathrm{b}}$ & 3.000 & 71.000 & .000 \\
\cline { 2 - 7 } & Hotelling's Trace & .812 & $12.659^{\mathrm{b}}$ & 3.000 & 71.000 & .000 \\
\cline { 2 - 7 } & Roy's Largest Root & .812 & $12.659^{\mathrm{b}}$ & 3.000 & 71.000 & .000 \\
\hline
\end{tabular}

The results of the Tests of Within-Subjects Effects are presented in Table 7. There was a significant effect of the units on students' scores, $F(3,219)=22.702, p=.000$. Specifically, there is a significant difference between the students' average score on the tests. The significance of $\mathrm{F}$ is .000 which means that there was a significant difference between students' scores for all the units. 
IADIS International Journal on WWW/Internet

Table 7. Tests of within-subjects effects

\begin{tabular}{|c|c|c|c|c|c|c|c|}
\hline Source & & $\begin{array}{l}\text { Type III Sum } \\
\text { of Squares }\end{array}$ & df & Mean Square & $\mathbf{F}$ & Sig. & $\begin{array}{l}\text { Partial } \\
\text { Eta } \\
\text { Square } \\
\text { d }\end{array}$ \\
\hline \multirow{4}{*}{ unit } & Sphericity Assumed & 152.764 & 3 & 50.921 & 22.702 & .000 & .217 \\
\hline & Greenhouse-Geisser & 152.764 & 2.608 & 58.575 & 22.702 & .000 & .217 \\
\hline & Huynh-Feldt & 152.764 & 2.697 & 56.642 & 22.702 & .000 & .217 \\
\hline & Lower-bound & 152.764 & 1.000 & 146.888 & 22.702 & .000 & .217 \\
\hline \multirow{4}{*}{ Error(unit) } & Sphericity Assumed & 491.213 & 219 & 2.243 & & & \\
\hline & Greenhouse-Geisser & 491.213 & 129.275 & 3.799 & & & \\
\hline & Huynh-Feldt & 491.213 & 143.192 & 3.430 & & & \\
\hline & Lower-bound & 491.213 & 52.986 & 9.271 & & & \\
\hline
\end{tabular}

Nonlinear trends were also tested as shown in Table 8. The results show a linear effect of the units on students' achievement as well as a quadratic effect for the interaction between the dependent and independent variable.

Table 8. Tests of within-subjects contrasts

\begin{tabular}{llllllll}
\hline Source & unit & $\begin{array}{l}\text { Type III } \\
\text { Sum of } \\
\text { Squares }\end{array}$ & df & Mean Square & F & Sig. & Partial Eta Squared \\
\hline \multirow{3}{*}{ unit } & Linear & 143.925 & 1 & 143.925 & 33.028 & .000 & .381 \\
\cline { 2 - 8 } & Quadratic & 1.682 & 1 & 1.682 & .627 & .429 & .013 \\
\hline \multirow{2}{*}{ Error } & Cubic & 6.079 & 1 & 6.079 & 2.786 & .102 & .050 \\
\hline & Linear & 235.121 & 73 & 4.428 & & & \\
\hline & Quadratic & 140.563 & 73 & 2.649 & & & \\
\hline
\end{tabular}

The pairwise comparisons are presented in Table 9 that show if the difference between each pair of units is significant. The only significant differences between group means were between units 1 and 4, units 2 and 3, and units 2 and 4.

Table 9. Pairwise comparisons

\begin{tabular}{|c|c|c|c|c|c|c|}
\hline \multirow[t]{2}{*}{ (I) unit } & \multirow[t]{2}{*}{ (J) unit } & \multirow[t]{2}{*}{$\begin{array}{l}\text { Mean } \\
\text { Difference }\end{array}$} & \multirow[t]{2}{*}{ Std. Error } & \multirow[t]{2}{*}{ Sig.b } & \multicolumn{2}{|c|}{$\begin{array}{l}\text { 95\% Confidence Interval for } \\
\text { Difference }^{b}\end{array}$} \\
\hline & & & & & Lower Bound & Upper Bound \\
\hline \multirow{3}{*}{1} & 2 & -.623 & .298 & .258 & -1.412 & .190 \\
\hline & 3 & $-1.785^{*}$ & .315 & .263 & -2.589 & -.938 \\
\hline & 4 (posttest) & $-2.104^{*}$ & .402 & .000 & -3.162 & -.945 \\
\hline 2 & 1 & .623 & .298 & .258 & -.190 & 1.412 \\
\hline
\end{tabular}




\begin{tabular}{|c|c|c|c|c|c|c|}
\hline & 3 & $-1.176^{*}$ & .287 & .002 & -1.948 & -.419 \\
\hline & 4 (posttest) & $-1.523^{*}$ & .358 & .001 & -2.396 & -.426 \\
\hline \multirow{3}{*}{3} & 1 & $1.785^{*}$ & .315 & .263 & .938 & 2.589 \\
\hline & 2 & $1.176^{*}$ & .287 & .002 & .419 & 1.948 \\
\hline & 4 (posttest) & -.247 & .354 & 1.000 & -1.176 & .703 \\
\hline \multirow{3}{*}{4 (posttest) } & 1 & $2.104^{*}$ & .402 & .000 & .945 & 3.162 \\
\hline & & $1.523^{*}$ & .358 & .001 & .426 & 2.396 \\
\hline & 3 & .247 & .354 & 1.000 & -.703 & 1.176 \\
\hline
\end{tabular}

Table 10 shows the estimates. The mean student score was 86.49 for unit $1 ; 87.13$ for unit 2, 88.17 for unit 3 , and 88.46 for unit 4. ANOVA shows that students' scores on the four units are significantly different, $\mathrm{F}(3,219)=22.702, \mathrm{p}<0.0005$. We can assume that there is a difference in the mean scores of the four units and in fact, it seems that the use of interactive multimedia technology in instruction causes an improvement in students' scores.

Table 10. Estimates

\begin{tabular}{lllll}
\hline unit & Mean & Std. Error & \multicolumn{2}{l}{ 95\% Confidence Interval } \\
\cline { 3 - 5 } & & & Lower Bound & Upper Bound \\
\hline 1 & 86.4930 & .784 & 84.914 & 88.089 \\
\hline 2 & 87.1375 & .714 & 85.665 & 88.478 \\
\hline 3 & 88.1754 & .724 & 86.852 & 89.867 \\
\hline 4 & 88.4657 & .484 & 87.571 & 89.613 \\
\hline
\end{tabular}

\section{CONCLUSION}

Educational technology tools such as interactive multimedia have the potential to improve student learning, achievement and motivation (Butts, 2008; Cottrell, 2014). The use of multimedia technology in instruction allows educational material to be combined and satisfy different learning modalities (Morano, 2014). Including more than one learning modality can be more effective in meeting students' needs (Malik, 2010). The purpose of this study was to examine if there were any significant differences in students' achievement scores in science for three units that were taught using traditional methods of instruction and a unit that was taught using educational technology tools in instruction and specifically, interactive multimedia technology. Results from one-way repeated measures ANOVA revealed that there was a change in students' scores throughout the four units. There was a statistically significant effect for the science units $F(3,219)=22.702, p<0.0005$. Students had a higher score on the posttest for unit 4 that was taught using interactive multimedia technology in instruction while they obtained lower scores on the tests for the three units that were taught using traditional methods of instruction. It is implied that the difference in students' scores is due to the use of interactive multimedia technology. This study presented an instructional method that was based on the use 
IADIS International Journal on WWW/Internet

of interactive multimedia technology that can be used as an advancing learning tool in order to help students promote and develop problem-solving and higher order thinking skills, while being engaged in active, experiential and constructivist learning. The results of the study depict the need for a change in student expectations as teaching methods develop into more active, student-centered and constructivist (Butts, 2008). Additionally, the findings of the current study illustrate that the use of educational technology tools in instruction such as multimedia can enhance student learning and achievement. In accordance with the theory of multimodal learning, the results of the study showed that students' achievement in science could be improved with the use of interactive multimedia technology in instruction. This finding extends results from previous studies that showed that the use of multimedia technology improved student learning and achievement (Adegoke, 2011; Dalal, 2014; So \& Kong, 2007). Multimedia technology tools include elements such as images, animations, sound, and video that can create a multi-modal learning environment and allow teachers to address students' different needs (Malik, 2010)

The current study tried to make a contribution to research on the use of educational technology tools such as interactive multimedia in elementary education. Additional research is still needed on this research area. Generalization of the results of this study was limited. It is therefore suggested that future research should include a population with different conditions with regards to sample size, student age, geography and subject matter. Multimedia present educational material in a multi-modal format and support more active student-centered learning environments (Chapman, 2013; Morano, 2014). Educational technology tools such as multimedia can challenge more students and increase their motivation in the classroom (Rhodes, 2013). The use of interactive multimedia technology in a constructivist learning environment can possibly bring about improvements in student learning outcomes.

\section{REFERENCES}

Adegoke, B.A. (2011). Effect of multimedia instruction on senior secondary school students' achievement in physics. European journal of Educational Studies, 3(3), 537-550.

Birgan, L.J. (2010). The effects of multimedia technology on students' perceptions and retention rates in mathematics at a community college (Ed.D., Northcentral University)., 109. In ProQuest Dissertations and Theses, (275867748).

Butts, L.J. (2008). Exploring constructivist learning environments: a case study (Ed.D., University of Houston). In ProQuest Dissertations and Theses, (304604619).

Chapman, D.L. (2013). Multimedia instructional tools and student learning in computer application courses. (Ph.D., The University of Southern Mississippi)., 154. ProQuest Dissertations and Theses. (1461743173).

Cottrell,T.L. (2014). An assessment of the effect of multimedia on critical thinking outcomes. (Northern Illinois University). , 202. In ProQuest Dissertations and Theses, (1554012341).

Dalal, M. (2014). Impact of multi-media tutorials in a computer science laboratory course-an empirical study. The Electronic Journal of e-Learning, 12(4), 366-374.

Delgado, A. (2007). The effects of multimedia technology on the learning of math story problems of elementary and middle school deaf students. (M.S., Lamar University - Beaumont). 57. In ProQuest Dissertations and Theses, (1452086).

Du, X. (2013). An empirical study on multimedia-based social constructivist model in English vocabulary acquisition. Journal of Language Teaching and Research, 4(5), 1036-1043. 


\section{ASSESSMENT OF THE EFFECTS OF EDUCATIONAL TECHNOLOGY TOOLS ON STUDENT}

LEARNING OUTCOMES

Garthwait, A. (2004). Use of hypermedia in one middle school: a qualitative field study. Journal of Educational Multimedia and Hypermedia, 13(3), 219-243.

Hunter, J. L., \& Krantz, S. (2010). Constructivism in cultural competence education. Journal of Nursing Education, 49(4), 207-14.

Johnson, T. (2009). The effect of closed interactive multimedia learning environments on student memory retention: A linear versus non-linear approach. (Ed.D., University of North Florida)., 120. In ProQuest Dissertations and Theses, (3354374).

Kingsley, K., \& Boone, R. (2008). Effects of multimedia software on achievement of middle school students in an american history class. Journal of Research on Technology in Education, 41(2), 203.

Malik, I.Z. (2010). Effects of multimedia-based instructional technology on African American ninth grade students' mastery of Algebra concepts. (Ed.D., University of Phoenix). In ProQuest Dissertations and Theses, (3452767)

Mazzotti, V.L. (2010). Effects of a multimedia goal-setting intervention on students' knowledge of the self-determined learning model of instruction and disruptive behavior. (Ph.D., The University of North Carolina at Charlotte). In ProQuest Dissertations and Theses, (3404854).

Morano, J.A. (2014). An exploration of multimedia reading instruction and its impact on students' online/offline reading comprehension. (Ph.D., Fordham University). , 219. In ProQuest Dissertations and Theses. (1561350869)

Neo, M., \& Neo, T.K. (2010). Students' perceptions in developing a multimedia project within a constructivist learning environment: a Malaysian experience. The Turkish Online Journal of Educational Technology, 9(1), 176-184.

Papanastasiou, E.C., \& Zembylas, M. (2004). Differential effects of science attitudes and science achievement in Australia, Cyprus, and the USA. International Journal of Science Education, 26(3), 259-280.

Ramos, P.H., \& De La Paz, S. (2010). Learning history in middle school by designing multimedia in a project-based learning experience. Journal of Research on Technology in Education, 42(2), 151-173.

Rhodes, A.E. (2013). The effect of teacher designed multimedia on student comprehension and retention rates within introductory college science courses. (Ph.D., Kansas State University)., 178. In ProQuest Dissertations and Theses. (1417767259).

Singleton, C.M. (2009). An examination of student attitudes and understanding of exponential functions using interactive instructional multimedia. (Ph.D., Southern University and Agricultural and Mechanical College)., 88. In ProQuest Dissertations and Theses, (3465446).

So, W.W., \& Kong, S. (2007). Approaches of inquiry learning with multimedia resources in primary classrooms. Journal of Computers in Mathematics and Science Teaching, 26(4), 329-354.

Stokes, S.D. (2011). A multi-metric assessment on the impact of I Can LearnRTM (ICL) multimedia on actual and perceived student achievement in developmental mathematics. (Ph.D., Southern University and Agricultural and Mechanical College)., 91. In ProQuest Dissertations and Theses, (3454223).

Trochim, W., \& Donnelly, J. (2008). The research methods knowledge base (3rd ed.). Mason, $\mathrm{OH}$ : Cengage Learning.

Ulusoy, K. (2011). Effects of multimedia usage in students' attitude towards Turkish Republic Revolution History and Kemalism Lesson. Educational Research and Reviews, 6(4), 358-366.

Weiss, I., Kramarski, B., \& Talis, S. (2006). Effects of multimedia environments on kindergarten children's mathematical achievements and style of learning. Educational Media International, 43(1), 3-17.

Yamauchi, L. (2008). Effects of multimedia instructional material on students' learning and their perceptions of the instruction. (M.S., Iowa State University)., 61. In ProQuest Dissertations and Theses, (1453140).

Zheng, R. Z., Yangt, W., Garcia, D., \& McCadden, E. P. (2008). Effects of multimedia and schema induced analogical reasoning on science learning. Journal of Computer Assisted Learning, 24(6), 474-482. 